\title{
Ortaokul 8. Sınıf Öğrencilerinin Okuma Ön Yargılarının Belirlenmesi
}

\author{
Erol Duran \\ Uşak Üniversitesi, Eğitim Fakültesi, Temel Eğitim Bölümü, Uşak \\ erol.duran@usak.edu.tr \\ ORCID ID: https://orcid.org/0000-0001-7581-3821 \\ Gülten Erkek \\ Uşak Üniversitesi Sosyal Bilimler Enstitüsü Türkçe Eğitimi Ana Bilim Dalı, Uşak \\ gultenerkek@hotmail.com \\ ORCID ID: https://orcid.org/0000-0002-3576-5711
}

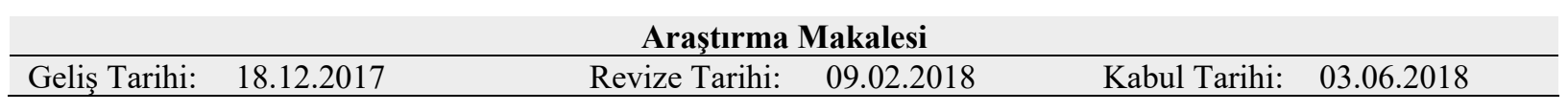

\section{Atıf Bilgisi}

Duran, E. ve Erkek, G. (2018). Ortaokul 8. sınıf öğrencilerinin okuma ön yargılarının belirlenmesi, Ahi Evran Üniversitesi Sosyal Bilimler Enstitüsü Dergisi, 4(1), 1-17. Doi: 10.31592/aeusbed.368064

\section{ÖZ}

Okuma alışkanlığı bireylerin zihinsel ve toplumsal gelişimlerine çok yönlü katkılarda bulunur. Ülkemizde okuma kültürünün gelişmiş ülke ortalamalarının oldukça altında olduğu bilinmektedir. Bu sorunun nedenlerinin araştırılması ve çözüm önerilerinde bulunulması ihtiyacı doğmuştur. Bir kimse veya bir şeyle ilgili olarak önceden edinilmiş olumlu veya olumsuz yargı, peşin hüküm olarak tanımlanan ön yarg1, öğrencilerin okuma alışkanlıklarını da etkilemektedir. Öğrencilerin okuma ön yargılarının giderilmesi, bu alışkanlığın kazandırılmasında büyük önem taşımaktadır. Bu araştırmada, 8. sınıf öğrencilerinin okuma ön yargılarının belirlenmesi ve çözüm önerilerinin betimlenmesi amaçlanmış̧ır. Bu amaç çerçevesinde 8. sınıf öğrencilerine, ön yargılarını belirleyici açık uçlu sorular sorulmuştur. Öğrencilerin verdiği cevaplara dayalı olarak veriler analiz edilmiştir. Öğrencilerin ortaya koyduğu düşüncelere göre ön yargılar değerlendirilmiş ve kitap okuma alışkanlığının önündeki engeller belirlenmiştir. Çalışma sonucunda en yüksek ön yargı sıklığı "Kitaplarla İlgili Ön Yargılar" başlığında tespit edilmiştir. Öğrencilerin anne-baba eğitim durumlarının okuma ön yargılarında anlamlı bir farklılık oluşturmadığ 1 sonucuna ulaşılmıştır. Öğrencilerin cinsiyetlerinin ön yargılardaki etkisi ise ayrı başlıklar şeklinde incelenmiştir. Aile, cinsiyet, öğretmen, teknolojik araçlar, kitaplar, lise giriş sınavları ve sosyal çevre etmenleri tek tek ele alınmış ve çözüm yolları tartışılmıştır.

Anahtar Kelimeler: Ön yarg1, okuryazarlık, okuma ön yargıs1

\section{Determination of Reading Prejudice at Secondary School $8^{\text {th }}$ Grade Students}

\begin{abstract}
Reading habits have multifunctional contributions to the mental and social developments of individuals. It is known that the reading culture in our country is far below the average of developed countries. The need for investigating the causes of this problem and suggesting solutions have arisen. The judgement either positive or negative acquired about a person or an object in advance, the prejudice which is defined as prejudgement, also affects the reading habits of students. The elimination of the reading prejudices of the students is of great importance in the acquisition of this habit. In this research, it has been aimed to determine the reading prejudices of $8^{\text {th }}$ grade students and to describe the solution suggestions. Within the scope of this purpose, open-end questions have been asked to the $8^{\text {th }}$ grade students for detecting their prejudices. The data based on the answers given by the students have been analysed. The prejudices have been evaluated according to the opinions suggested by the students, and the obstacles about reading habits have been determined. At the end of the study, the highest prejudice frequency has been detected under the title of "Prejudices About Books". It has been concluded that the educational background of the parents does not make a meaningful difference on the reading prejudices of the students. The effect of the genders of the students upon their prejudices has been examined as separate titles. The elements such as family, gender, teachers, technological tools, books, high school entrance exams and social environmental factors have been handled one by one and keys for solutions have been discussed.
\end{abstract}

Keywords: prejudice, literacy, reading prejudice

\section{Giriş}

Bireylerin hayatında çok önemli bir yere sahip olan okumanın birçok tanımına rastlamak mümkündür: Okuma, dünyanın gelişmesi ve derinleşmesine uyum sağlayabilmemizi sağlayan bir araç (Bircan ve Tekin, 1989; Kurulgan ve Çekerol, 2008); Mete'ye göre (2012), bireylerin kişisel ve toplumsal gelişimini sağlayan bir değer; Chua'ya (2008) göre ise, bir meslek sahibi olmak için 
yapılacak bir etkinlikten ziyade kişinin kendini anlayabilmesi için gerçekleştirilmesi gereken bir iş olarak tanımlanmaktadır. Özetle okuma, yaşamı anlamlandırma sürecidir (Batur vd., 2010; İșcan vd., 2013).

Toplumsal eğitimin anahtarı (Özbay vd., 2008) ve bireyin kişiliğini geliştiren, düşünce dağarcığını zenginleştiren en önemli araç (Yılmaz, 2006) olarak kabul edilen, bir gereksinim ve zevk kaynağı olarak algılanması sonucu yaşam boyu düzenli bir şekilde gerçekleştirilen (Arslan vd., 2009; Balc1, 2009) okuma alışkanlığının eğitimde önemli bir yeri vardır. Bu alışkanlığı edinen bireyler, kendilerini daha iyi ve doğru biçimde ifade edebilir; yaratıcılıklarını, yeteneklerini, soyut düşünceleri ile hayal güçleri ve diğer zihinsel becerilerini geliştirebilirler (Aksaçlığlu ve Yılmaz, 2007). Ayrıca bu bireyler doğaya, insanlara, doğadaki diğer canlılara ve olaylara karşı da hassasiyet geliştirirler (Tanju, 2010). Okuma sayesinde kişi, yaşadığı topluma ve kültürel çevreye uyum sağlayabilir, bilgi ve deneyim kazanarak geleceğe daha iyi hazırlanabilir. Okuma eylemi sırasında öğrenciler yeni bilgi kaynaklarına ve yeni tecrübelere ulaşma imkanı bulur (Yıldız ve Keskin, 2016).

Üst düzey okuma gelişimlerinden biri de okumanın alışkanlık haline dönüşmesidir (Balcı vd., 2012). Pek çok kaynakta okuma alışkanlığı olan öğrencilerin bu becerilerini sürekli geliştirdikleri, farklı metinlerle ilgili tecrübe kazandıkları ve bu sayede okumadan daha fazla keyif aldıkları belirtilmektedir (Sanacore, 2000). Bu nedenle okuma alışkanlığı toplumsal gelişmişliğin ve medeniyetin ölçütlerinden biri olarak görülmektedir (Mete, 2012; Durualp vd., 2013). Birey, bilgi birikimi ve eleştirel düşünme becerisini okuma ile geliştirmiş olacaktır.

Ülkemizde okuma alışkanlığının yeterli düzeyde olmadığını belirten görüşlere sıkça rastlanmakta ve okuma kültürümüzün gelişmiş ülke ortalamalarının oldukça altında olduğu vurgulanmaktadır. Burada sorun okuma alışkanlığımızın zaman içerisinde azalması değil, küçük yaşlardan itibaren kazandırılamamasıdır (Bircan ve Tekin, 1989).

Alanyazın değerlendirildiğinde çocukların okuma alışkanlığı edinmelerinde aile ve okul çevresindeki okuma deneyimlerinin oldukça etkili olduğu görülmektedir (Anderson vd., 1996; Smith vd., 1998). Bu nedenle çalışmalarda öncelikle okuma çevrelerinin tanımlanıp çocukların okuma alışkanlıklarını destekleyecek bir çevre oluşturulmasına çalışılmıştır.

Öğrencileri okumaya yönelten nedenler okuma motivasyonu ile ilgilidir. Öğrenciler, ilgi ve meraklarını kapsayan içsel nedenlerle okumaya yönelebilecekleri gibi, aile, arkadaş, okul, öğretmen vb. nedenlerle de okumaya yönelebilirler (Yıldız ve Akyol, 2011).

Kitap okuma alışkanlığı edinmenin önde gelen koşulu, okumaya karşı olumlu tutum geliştirmektir. Günümüz eğitim kurumlarında, bu alışkanlıkla ilgili eksiklikler söz konusudur. Belirtilen bu olumsuzluğun giderilmesi için, öğrencilerin okuma ön yargılarının tespit edilerek motivasyonlarının sağlanması ihtiyacı ortaya çıkmaktadır.

\section{Okuma Ön Yargısı}

Bireylerin veya herhangi bir şeyin lehinde ya da aleyhindeki fikir, peşin hükümde bulunma olarak tanımladığımız ön yargı, psikolojideki kullanımında, sadece inançlar ve fikirler hakkında peşin hükmü değil, aynı zamanda duygusal çağrışımı da içerdiğinden geniş bir anlam kazanmıştır (Gürses, 2005). Ön yarg1, en genel anlamı ile bir taraf olma durumudur. İdeolojik, dini, etnik, mezhepsel, cinsiyete veya yaşa dayalı bir çok ön yargı biçiminden bahsetmek mümkündür. Ön yargıların zihinsel belirtisi kalıp yargılar, davranışsal belirtisi ise ayrımcılıktır (Jones, 2002).

Ön yargıların çoğu anne baba başta olmak üzere diğer ön yargıll kişilerden öğrenilir. Ön yargılı anne babalar bilinçli veya bilinçsiz şekilde çocuklarını ön yargılı olacak biçimde yetiştirirler (Gürses, 2005). Ancak ön yarg1 sadece anne ve babadan öğrenilmez. Öğretmenler, okul arkadaşları ve basın da ön yargıların oluşumuna katkıda bulunabilir (Bostanoğlu, 2005). Bu nedenle ön yargıları sadece insanın doğal eğilimine bağlamak yerine öğrenme sürecinin bir parçası olarak da görmek gerekmektedir. 
Çocukların okuma tutumları özellikle içinde büyüyüp yetiştikleri aile ve okul çevresiyle yakından ilgilidir. Schunk ve Zimmerman (2007) tarafından yapılan çalışmada yetişkin ve akranların çocukların yaşantılarında model oldukları ifade edilmektedir. Okumada ilgi ve ihtiyaçlar bireyleri harekete geçirmede (Ülper ve Çeliktürk, 2013); öğretmen, aile arkadaş, kitap, ortam ve etkinlik etmenleri de öğrencilerde okuma isteği uyandırmada belirleyici rol oynamaktadır.

Öğrencilerin okuma ile ilgili ön yargıları da genellikle aile, okul, öğretmen, sosyal çevre ve kitaplarla ilgilidir. Rol model olmanın ilk ve en önemli basamağ 1 olan aile, günümüzde öğrenciler için okumaya karşı olumsuz motivasyona neden olan bir unsur olarak karşımıza çıkmaktadır. Ailelerin baskıcı ya da ilgisiz olması, sınav kaygısıyla birlikte test çözmeye yöneliş, aile ya da okulun imkanları dâhilinde öğrencilerin ilgi çekici kitaplarla buluşturulamaması, olumsuz akran modelleri vb. birçok nedenle öğrencilerin okuma motivasyonları sağlanamamaktadır.

Ön yargıların azaltılması için buna neden olan kalıp yargıların azaltılması ve buna dair algıların değiştirilmesi en makul yol olarak görünmektedir (Sağıroğlu, 2014). Sağıroğlu'na göre alg1 değişikliğini gerçekleştirmenin en etkili yolu, bakış açısını değiştirmektir. Diğer bir deyişle ön yargıların azalmasında "empati" becerisinin oluşturulması ve devam ettirilmesi önemli rol oynar. Empati eğitim programlarının yaş, cinsiyet ve ırk değişkenlerine dayalı ön yargıların azaltılmasında oldukça başarılı olduğu görülmüştür (Plous, 2003).

Öğrencilere okuma alışkanlığı kazandırabilmek için okumayı sevmeye engel teşkil eden unsurların bilinmesi ve bu konuda yapılan çalışmaların sunulması gerekmektedir (Arıc1, 2008). Ön yargıların oluşmasını engelleme konusunda en etkin kişiler anne baba ve öğretmenlerdir. Küçük yaşlarda oluşmaya başlayan ön yargılar zamanla azaltılıp yok edilmediğinde kalıcılaşmaktadır. Ortaokul çağındaki çocukların bedensel, duyuşsal ve zihinsel becerileri ile birlikte ön yargıları da hızla gelişmektedir. $\mathrm{Bu}$ nedenle okumanın, yalnızca bir öğüt olarak kalmaması, sözlerin davranışlarla desteklenmesi, öğrencilerin okumaya karşı olumsuz ön yargılarının tespiti ve giderilmesi, bu alışkanlığın kazanılmasında büyük önem taşımaktadır.

\section{Araştırmanın Amacı}

Okuma bireyin kişiliğini geliştirir, düşünce dağarcığını zenginleştirir ve en önemlisi toplumsal eğitimin anahtarı kabul edilir. Okumanın alışkanlık haline dönüşmesi ise üst düzey bir gelişimin göstergesidir. Öğrencilerin okuma ön yargılarının tespit ve analizi bu alışkanlığın kazandırılmasında büyük önem taşımaktadır. Bu çalışmada, 8. sınıf öğrencilerinin okuma ön yargıları ortaya konulmaya çalışılmıştır. Bu amaç doğrultusunda araştırmanın alt problemleri şu şekilde belirlenmiştir:

1- 8. sınıf öğrencilerinin okuma ön yargılarını etkileyen faktörlerin sıklık düzeyleri

a. cinsiyete göre,

b. anne baba eğitim durumuna göre farkl1l1k göstermekte midir?

2- 8. sınıf öğrencilerinin okuma ön yargılarını etkileyen faktörlerle ilgili görüşleri nelerdir?

\section{Yöntem}

$\mathrm{Bu}$ araştırmada, olay ve olguları sosyal özelliği olan insana göre ele alan nitel araştırma modeli kullanılmıştır. Ortaokul 8. sınıf öğrencilerinin, okuma önyargılarını berlielemeye yönelik yapılan bu çalışma, nitel araştırma desenlerinden biri olan, durum çalışması deseni ile kurgulanmıştır. Durum çalışmaları, 'nasıl' ve 'niçin' sorularına cevap arayan; araştırmacının kontrol edemediği bir olgu ya da olayı ayrıntılı incelemeyi amaç edinen çalışmalardır (Yıldırım ve Şimşek, 2008).

\section{Çalışma Grubu}

Nitel araştırmalarda mümkün olduğunca evrende olması muhtemel bütün çeşitliliği temsil edecek genel bir bakış sağlanmaya çalışılır (Karataş, 2015) Bu çalışmada, Uşak ilinde 2017-2018 eğitim-öğretim yılında 8. sınıfa devam eden 20 kız, 20 erkek öğrenci olmak üzere toplam 40 öğrenci 
çalışma grubunu oluşturmaktadır. Çalışma grubunu oluşturan 40 öğrencinin 13'ünün anne eğitim durumu ilkokul, 9'unun ortaokul, 7'sinin lise ve 11'inin üniversite seviyesindedir. Çalışma gurubunun baba eğitim durumları ise şu şekildedir: 8 ilkokul, 9 ortaokul, 13 lise ve 10 üniversite mezunu. Çalışma grubu, gönüllülük esası ve kolay ulaşılabilirlik ilkesi göz önünde tutularak oluşturulmuştur.

\section{Veri Toplama Aracı ve Verilerin Toplanması}

Bu çalışmada 8. sınıf öğrencilerinin okuma ön yargılarını belirlemek amacıyla açık uçlu yedi sorudan oluşan yarı yapılandırılmış görüşme formu kullanılmıştır. Form, üç uzman görüşü doğrultusunda düzenlenerek son şeklini almıştır. Görüşme formunda yer alan sorular şu şekildedir:

Kitap okuma alışkanlığının,

a. cinsiyete göre,

b. ailelerin tutumlarına göre,

c. ögretmenlerin tutumlarına göre,

d. sahip olunan sosyal çevreye göre,

e. kitapların niteliklerine göre,

f. lise giriş sınavı ile ilgili düşünce ve beklentilere göre farklılaştığını düşünüyor musunuz? Neden?

\section{Geçerlik ve Güvenirlik}

Nitel araştırmalarda elde dilen bilgilerin geçerlik ve güvenirliğinin sağlanmasında kullanılan yöntemlerden biri de "özneler arası geçerlilik"tir. Bu geçerlilik yönteminde verilerin uzmanlarca bağımsız şekilde değerlendirilmesi ve sonuçların karşılaştırılması söz konusudur (Hall ve Lindey, 1985; akt. Özdemir, 2010). Bu çalışmada nitel araştırmalarda kullanılan tutarlık, aktarılabilirlik ve teyit edilebilirlik kavramları gözönünde bulundurularak geçerlik ve güvenirlik sağlanmaya çalışılmıştır.

Araştırma verileri uzman görüşleri alınarak oluşturulmuştur. Alanında uzman üç araştırmacı tarafından ortak noktalar incelenerek nesnel şekilde sunulmaya çalışılmıştır. Çalışma grubu, amaçlı örneklem yoluyla oluşturulmuştur. Ayrıca ikinci alt problemde katılımcıların söylemlerinden örnek cümlelere yer verilerek kapsam geçerliliğine katkı sağlanmıştır.

\section{Verilerin Analizi}

Araştırmanın birinci alt problemi için betimsel analiz kullanılmıştır. Betimsel analizde öncelikle veriler toplanır daha sonra bu veriler değiştirilmeden aktarılır. Öğrenciler veri tablolarında K1, K2, K3... (Katılımcı 1, Katılımcı 2, Katılımcı 3...) şeklinde adlandırılmıştır. Araştırmanın ikinci alt probleminde tematik kodlama yapılarak elde edilen veriler kategorileştirilmiştir. Her kategori için yüzdelik oranlar ve örnek ifadeler verilmiştir. Öğrencilerin görüşleri, literatürde yer alan diğer bulgu ve yorumlarla karşılaştırılarak değerlendirilmiştir.

\section{Bulgular}

Araştırmada elde edilen veriler 1şığında ulaşılan bulgular, alt problem sırası dikkate alınarak açıklanmıştır. "8. sınıf ögrrencilerinin okuma ön yargılarını etkileyen faktörlerin sıklık düzeylerinin, cinsiyet ve anne baba eğitimi durumu değişkenine göre durumları" Tablo 1 ve Tablo 2 'de verilmiştir. 


\section{Birinci Alt Probleme İlişskin Bulgular ve Yorumlar}

8. sınıf öğrencilerinin okuma önyargılarını etkileyen faktörlerin cinsiyet değişkenine göre sıklık düzeyi, Tablo 1'de gösterilmiştir.

\section{Tablo 1}

8. Sinıf Öğrencilerinin Cinsiyet Değişkenine Göre Okuma Ön Yargıları

\begin{tabular}{|c|c|c|c|c|c|c|c|c|}
\hline 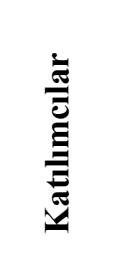 & 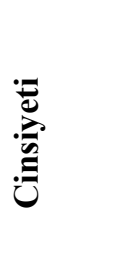 & 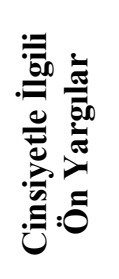 & 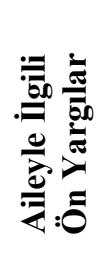 & 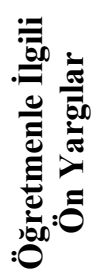 & 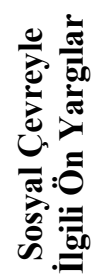 & 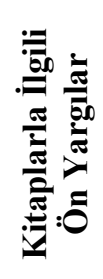 & 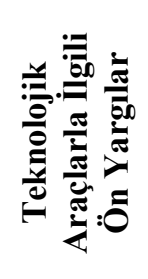 & 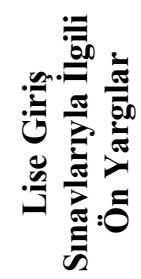 \\
\hline K1 & Kız & & $\mathrm{X}$ & $\mathrm{X}$ & $\mathrm{X}$ & $\mathrm{X}$ & & $\mathrm{X}$ \\
\hline K2 & Kız & & $X$ & $\mathrm{X}$ & $X$ & $X$ & & $\mathrm{X}$ \\
\hline K3 & Kız & & $X$ & $\mathrm{X}$ & & X & $\mathrm{X}$ & X \\
\hline K4 & Kız & & $X$ & & $X$ & X & & X \\
\hline K5 & Kız & & $X$ & $\mathrm{X}$ & $X$ & X & & X \\
\hline K6 & Kız & & $\mathrm{X}$ & $X$ & $X$ & X & & X \\
\hline K7 & $\mathrm{K} 1 \mathrm{z}$ & & $\mathrm{X}$ & $X$ & $X$ & X & & \\
\hline K8 & $\mathrm{K} 1 \mathrm{z}$ & & & & $X$ & X & & $\mathrm{X}$ \\
\hline K9 & $\mathrm{K} ı \mathrm{z}$ & & X & $\mathrm{X}$ & & X & $\mathrm{X}$ & X \\
\hline K10 & Kız & & $\mathrm{X}$ & $\mathrm{X}$ & $X$ & $X$ & & \\
\hline K11 & $\mathrm{K} ı \mathrm{z}$ & X & X & $\mathrm{X}$ & & X & $\mathrm{X}$ & X \\
\hline K12 & Kız & & $\mathrm{X}$ & $\mathrm{X}$ & $X$ & $X$ & & $\mathrm{X}$ \\
\hline K13 & Kız & $X$ & & $\mathrm{X}$ & $X$ & $X$ & $\mathrm{X}$ & $X$ \\
\hline K14 & Kız & & $X$ & $X$ & $X$ & X & $\mathrm{X}$ & $\mathrm{X}$ \\
\hline K15 & Kız & & & & $X$ & X & & X \\
\hline K16 & Kız & & $X$ & $X$ & & X & X & X \\
\hline K17 & Kız & & $\mathrm{X}$ & $\mathrm{X}$ & & $\mathrm{X}$ & $X$ & $\mathrm{X}$ \\
\hline K18 & $\mathrm{K} 1 \mathrm{z}$ & $X$ & & & & $X$ & & $\mathrm{X}$ \\
\hline K19 & $\mathrm{K} 1 \mathrm{z}$ & & X & & & X & & \\
\hline K20 & $\mathrm{K} 1 \mathrm{Z}$ & & X & $\mathrm{X}$ & X & X & & \\
\hline K21 & Erkek & & & $X$ & $X$ & $X$ & $\mathrm{X}$ & $\mathrm{X}$ \\
\hline K22 & Erkek & & & & & & $\mathrm{X}$ & X \\
\hline K23 & Erkek & $\mathrm{X}$ & & & & X & & X \\
\hline K24 & Erkek & & & $X$ & & $X$ & $\mathrm{X}$ & $\mathrm{X}$ \\
\hline K25 & Erkek & & $X$ & $X$ & $X$ & X & X & \\
\hline K26 & Erkek & & $\mathrm{X}$ & $X$ & & $X$ & & $\mathrm{X}$ \\
\hline K27 & Erkek & & $X$ & & & X & X & \\
\hline K28 & Erkek & & & & & $X$ & & $\mathrm{X}$ \\
\hline K29 & Erkek & & & & X & X & X & X \\
\hline K30 & Erkek & & $X$ & $X$ & & X & $\mathrm{X}$ & X \\
\hline K31 & Erkek & X & $X$ & $X$ & & X & $\mathrm{X}$ & X \\
\hline K32 & Erkek & & $X$ & & $X$ & X & $\mathrm{X}$ & X \\
\hline K33 & Erkek & $\mathrm{X}$ & $\mathrm{X}$ & $\mathrm{X}$ & $\mathrm{X}$ & $X$ & & $X$ \\
\hline K34 & Erkek & & & $X$ & & X & & \\
\hline K35 & Erkek & $\mathrm{X}$ & $\mathrm{X}$ & $\mathrm{X}$ & & $\mathrm{X}$ & $X$ & $X$ \\
\hline K36 & Erkek & & X & X & & X & & X \\
\hline K37 & Erkek & & X & X & & X & X & \\
\hline K38 & Erkek & X & X & X & & & X & \\
\hline K39 & Erkek & & $\mathrm{X}$ & & & $X$ & $X$ & $\mathrm{X}$ \\
\hline K40 & Erkek & $X$ & & & & $X$ & $\mathrm{X}$ & $X$ \\
\hline Toplam & 40 & 9 & 28 & 27 & 18 & 38 & 21 & 31 \\
\hline
\end{tabular}

8. sınıf öğrencilerinin okuma ön yargıları yedi alt başlıkta incelenmiştir: Cinsiyetle İlgili Ön Yargılar, Aileyle İlgili Ön Yargılar, Öğretmenle İlgili Ön Yargılar, Sosyal Çevreyle İlgili Ön Yargılar, 
Kitaplarla İlgili Ön Yargılar, Teknolojik Araçlarla İlgili Ön Yargılar, Lise Giriş Sınavlarılla İlgili Ön Yargilar.

Tablo 1 incelendiğinde ön yargı sıklı̆̆ının en düşük olduğu başlığın "Cinsiyetle İlgili Ön Yargılar" başlığı olduğu göze çarpmaktadır. Kız öğrencilerin yalnızca üçünde cinsiyetle ilgili ön yargıların bulunduğu görülmektedir. $\mathrm{Bu}$ nedenle tablodaki en düşük sıklık oranı \%15 ile kız öğrencilerin cinsiyet ön yargılarına aittir. Bu oran erkek öğrencilerde \%30’a yükselmektedir.

8. sınıf öğrencilerinde görülen ön yarılarda en yüksek 3. orana sahip olan “Aileyle İlgili Ön Yargılar" incelendiğinde ön yarg1 sıklıklarının hem kız hem de erkek öğrencilerde yükseldiği görülmektedir. Kız öğrencilerin yalnızca dördünde görülmeyen bu ön yargının grupta görülme oranı $\% 80$ 'dir. Erkek öğrencilerde bu oran 12 öğrenci ile \%60'a düşmektedir. Toplam 28 öğrencide görülen aileyle ilgili ön yargıların bu başlıktaki sıklık oranı \% 70 'tir.

Öğretmenle ilgili okuma ön yargıları, \%67,5 ön yarg1 sıklığı ile toplam 27 öğrencide görülmektedir. 27 öğrencinin 15'i kı, 12'si erkek öğrencidir. Öğretmenle ilgili ön yargıların gruplarda görülme sıklığ 1 kız öğrencilerde \% 75 , erkek öğrencilerde \%60 olarak tespit edilmiştir. Bu başlık da ön yargı siralamasında 4 . sirada yer almaktadır.

Aile ve öğretmenle ilgili ön yargılar, motivasyonun okuma üzerindeki etkisi ile ilgilidir. Oranlar, öğrencilerin okuma ön yargılarında gerek aile gerekse öğretmenin rol model olmasının belirleyici olduğunu göstermektedir.

Cinsiyetle ilgili ön yargılardan sonra okuma ön yargısı sıklığının en az olduğu başlık "Sosyal Çevreyle İlgili Ön Yargılar" başlığıdır. 18 öğrencide görülen bu ön yargının sıklık oranı \%45'tir. Kız öğrencilerin 13 tanesinde görülen sosyal çevre ön yargılarının erkek öğrencilerin yalnızca beşinde görülmesi dikkat çekicidir.

En yüksek ön yargı sıklı̆̆ 38 öğrenci ile "Kitaplarla İlgili Ön Yargılar" başlığında tespit edilmiştir. İki erkek öğrenci dışındaki tüm katılımcılarda bu ön yargı görülmektedir. Sıklık oranları kız öğrencilerde \%100, erkek öğrencilerde ise \%90'dır. Kitapların nitelikleri öğrencileri okumaya yöneltmekte ya da okumadan uzaklaştırmaktadır. Bu oranlar, öğrencilerin farklı niteliklere sahip kitaplarla buluşturulması ve kitap seçimlerinde baskıcı bir tutum izlenmemesinin önemini vurgular niteliktedir.

Teknolojik araçlarla ilgili ön yargılar incelendiğinde kız öğrencilerin \%35'inde bu ön yarg1 görülmektedir. Erkek öğrencilerde ise oranın 14 öğrenci ile \%70' e yükseldiği tespit edilmiştir. Erkek öğrenciler hızlı ve keyifli buldukları teknolojik araçlarla daha fazla vakit geçirmekte ve buna bağlı olarak okumadan uzaklaşmaktadırlar.

8. sınıf öğrencisi olan katılımcıların büyük bir oranda lise giriş sınavlarıyla ilgili ön yargılara sahip oldukları görülmektedir. Söz konusu ön yargının 31 öğrencide görüldüğ̈̈ ve görülme sıklığının $\% 77,5$ olduğu tespit edilmiştir. Kız ve erkek öğrencilerin lise giriş sınavlarıyla ilgili ön yarg1 oranlarının yakın olması dikkat çekicidir. (Kız öğrenciler \%80, erkek öğrenciler \%75) Bu konuda hem aileler hem de öğretmenlerin beklenti ve yanlış düşünceleri öğrencilerde ön yargıların temelini oluşturmaktadır. Öğrenciler kitap okumayı, lise giriş sınavına hazırlanmalarını engelleyici bir unsur ve zaman kaybı olarak görmektedirler.

Kız öğrencilerde en yüksek ön yargı sıklığı "Kitaplarla İlgili Ön Yargılar" başlığında tespit edilmiştir. Bu ön yargının grup içindeki sıklık oranı \%100'dür. Kız öğrencilerin diğer ön yargı sıklıkları sırasıyla şöyledir: Aileyle İlgili Ön Yargılar (\%80), Lise Giriş Sınavlarıyla İlgili Ön Yargılar (\%80), Öğretmenle İlgili Ön Yargılar (\%75), Sosyal Çevreyle İlgili Ön Yargılar (\%65), Teknolojik Araçlarla İlgili Ön Yargılar (\%35) ve Cinsiyetle İlgili Ön Yargılar (\%15) Benzer şekilde erkek öğrencilerde en yüksek ön yargı sıklığ $1 \% 90$ sıklık oranı ile "Kitaplarla İlgili Ön Yargılar" başlığında görülmektedir. Erkek öğrencilerin diğer ön yargı sıklıkları sırasıyla şöyledir: Lise Giriş Sınavlarıyla İlgili Ön Yargılar (\%75), Teknolojik Araçlarla İlgili Ön Yargılar ( \%70), Aileyle İlgili Ön Yargılar 
(\%60), Öğretmenle İlgili Ön Yargılar (\%60), Cinsiyetle İlgili Ön Yargılar (\%30) ve Sosyal Çevreyle İlgili Ön Yarg1lar (\%25)

8. sınıf öğrencilerinin okuma ön yargılarını etkileyen faktörlerin anne baba eğitim durumu değişkenine göre sıklık düzeyi, Tablo 2'de gösterilmiştir.

Tablo 2

8. Sinıf Öğrencilerinin Anne-Baba Ĕ̈itim Durumlarına Göre Okuma Ön Yargıları

\begin{tabular}{|c|c|c|c|c|c|c|c|c|}
\hline : & 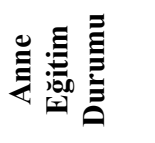 & 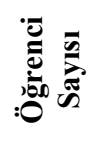 & 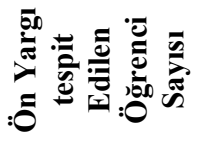 & ప̃ & 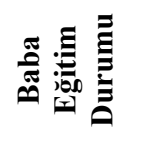 & 盛 & 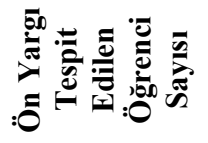 & 氞 \\
\hline Cinsiyetle & İlkokul & 13 & 3 & $\% 23$ & İlkokul & 8 & 0 & $\% 0$ \\
\hline İlgili Ön & Ortaokul & 9 & 2 & $\% 22$ & Ortaokul & 9 & 0 & $\% 0$ \\
\hline \multirow[t]{2}{*}{ Yargilar } & Lise & 7 & 1 & $\% 14$ & Lise & 13 & 5 & $\% 38$ \\
\hline & Üniversite & 11 & 3 & $\% 27$ & Üniversite & 10 & 4 & $\% 40$ \\
\hline Aileyle & İlkokul & 13 & 8 & $\% 61$ & İlkokul & 8 & 5 & $\% 62$ \\
\hline İlgili & Ortaokul & 9 & 6 & $\% 66$ & Ortaokul & 9 & 6 & $\% 66$ \\
\hline \multirow{2}{*}{ Ön Yargılar } & Lise & 7 & 6 & $\% 85$ & Lise & 13 & 10 & $\% 76$ \\
\hline & Üniversite & 11 & 8 & $\% 72$ & Üniversite & 10 & 7 & $\% 70$ \\
\hline Öğretmenle & İlkokul & 13 & 7 & $\% 53$ & İlkokul & 8 & 4 & $\% 50$ \\
\hline İlgili Ön & Ortaokul & 9 & 6 & $\% 66$ & Ortaokul & 9 & 6 & $\% 66$ \\
\hline \multirow[t]{2}{*}{ Yargilar } & Lise & 7 & 7 & $\% 100$ & Lise & 13 & 10 & $\% 76$ \\
\hline & Üniversite & 11 & 7 & $\% 63$ & Üniversite & 10 & 7 & $\% 70$ \\
\hline Sosyal & İlkokul & 13 & 7 & $\% 53$ & İlkokul & 8 & 5 & $\% 62$ \\
\hline Çevreyle & Ortaokul & 9 & 5 & $\% 55$ & Ortaokul & 9 & 6 & $\% 66$ \\
\hline İlgili Ön & Lise & 7 & 3 & $\% 42$ & Lise & 13 & 5 & $\% 38$ \\
\hline Yargilar & Üniversite & 11 & 3 & $\% 27$ & Üniversite & 10 & 2 & $\% 20$ \\
\hline Kitaplarla & İlkokul & 13 & 11 & $\% 84$ & İlkokul & 8 & 7 & $\% 87$ \\
\hline İlgili Ön & Ortaokul & 9 & 9 & $\% 100$ & Ortaokul & 9 & 9 & $\% 100$ \\
\hline \multirow[t]{2}{*}{ Yargilar } & Lise & 7 & 7 & $\% 100$ & Lise & 13 & 12 & $\% 92$ \\
\hline & Üniversite & 11 & 11 & $\% 100$ & Üniversite & 10 & 10 & $\% 100$ \\
\hline Teknolojik & İlkokul & 13 & 8 & $\% 61$ & İlkokul & 8 & 5 & $\% 62$ \\
\hline Araçlarla & Ortaokul & 9 & 3 & $\% 33$ & Ortaokul & 9 & 3 & $\% 33$ \\
\hline İlgili Ön & Lise & 7 & 3 & $\% 42$ & Lise & 13 & 8 & $\% 61$ \\
\hline Yargilar & Üniversite & 11 & 7 & $\% 63$ & Üniversite & 10 & 5 & $\% 50$ \\
\hline Lise Giriş & İlkokul & 13 & 9 & $\% 69$ & İlkokul & 8 & 5 & $\% 62$ \\
\hline Sinavlarıyla & Ortaokul & 9 & 7 & $\% 77$ & Ortaokul & 9 & 7 & $\% 77$ \\
\hline İlgili Ön & Lise & 7 & 5 & $\% 71$ & Lise & 13 & 11 & $\% 84$ \\
\hline Yargılar & Üniversite & 11 & 10 & $\% 90$ & Üniversite & 10 & 8 & $\% 80$ \\
\hline
\end{tabular}

Katılımcıların \%32'sinin anne eğitim durumu ilkokul seviyesindedir. Onu sırasıyla üniversite (\%27), ortaokul (\%22) ve lise (\%17) düzeyindeki eğitim durumları izlemektedir.

Cinsiyetle ilgili ön yargıların anne eğitim durumuna göre oranları incelendiğinde en yüksek oranın \%27 ile üniversite eğitim düzeyinde görüldüğü göze çarpmaktadır. En düşük oran ise \%14 ile lise eğitim düzeyinde görülmektedir.

Aileyle ilgili ön yargılarda ise en yüksek oran \%85 ile lise eğitim düzeyindedir. "Öğretmenle İlgili Ön Yargılar" başlığında da en yüksek oranın lise eğitim düzeyinde görülmesi dikkat çekicidir.

Sosyal çevreyle ilgili ön yargılarda en yüksek oran $\% 55$ ile ortaokul düzeyine aittir. "Kitaplarla İlgili Ön Yargılar" başlığında ilkokul düzeyi dışındaki tüm eğitim düzeylerinde oran $\% 100$ 'dür. Bu oran ailelerin çocuklarını doğru kitaplarla buluşturmasının gerekliliğini ortaya koymaktadır. Ailelerin eğitim durumlarına göre sosyoekonomik düzeylerinin de yükselmesine bağlı olarak özellikle anne eğitim durumu üniversite seviyesinde olan öğrencilerin kitaplarla ilgili ön yargılarında düşüş olmaması dikkat çekicidir. Bu durum, eğitim seviyesinin sağladığı imkânlara karşın anne babaların çocuklarına zaman ayıramadıklarını düşündürmektedir. Benzer şekilde öğretmenlerin öğrencileri doğru kitaplarla buluşturamaması ve öğrencilerin bu konudaki ön yargılarını önleyici çalışmalarda yetersiz kalması da söz konusudur. 
Teknolojik araçlar (\%63) ve lise giriş sınavlarıyla (\%90) ilgili ön yargılarda üniversite eğitim düzeyinin en yüksek orana sahip olduğu görülmektedir. Bu durumun üniversite mezunu ailelerin öğrencilere sunduğu teknolojik imkanlar, lise giriş sınavlarıyla ilgili beklentileri ve çocuklarına ayırabildikleri zamanla ilgili olduğu düşünülmektedir.

Katılımcıların \%32'sinin baba eğitim durumu lise seviyesindedir. Onu sırasıly üniversite $(\% 40)$, ortaokul (\%22) ve ilkokul (\%20) düzeyindeki eğitim durumları izlemektedir.

Cinsiyetle ilgili ön yargılarda en yüksek oran \%40 ile üniversite eğitim düzeyinde görülürken ilk ve ortaokul düzeylerinde ön yargı tespit edilmemiştir. Cinsiyetle ilgili ön yargıların anne baba eğitim durumu yükseldikçe artması dikkat çekicidir. Aile (\%76) ve öğretmenle (\%76) ilgili ön yargılarda lise grubunun öne çıktı̆̆ 1 göze çarpmaktadır. Bu sonuçlar, anne eğitim durumlarındaki sonuçlarla örtüşmektedir.

"Sosyal Çevreyle İlgili Ön Yargılar" başlığında da, anne eğitim seviyesi sonuçlarına benzer şekilde, \%66 ile ortaokul eğitim düzeyi en yüksek orana sahiptir. Kitaplarla ilgili ön yargılar, baba eğitim düzeyi ortaokul ve üniversite olan öğrencilerin tamamında görülmektedir. Teknolojik araçlarla ilgili ön yargılarda ilkokul (\%62), lise giriş snnavıyla ilgili ön yargılarda ise lise (\%84) düzeyi en yüksek orana sahiptir. Bu sonuç, anne eğitim seviyesi sonuçlarıyla çelişmektedir.

Öğrencilerin anne baba eğitim durumları ile okuma ön yargıları arasında anlamlı bir farktan söz edilememektedir. Ön yargı başlıklarında anne baba eğitim seviyelerine göre kademeli bir yükseliş ya da düşüş söz konusu değildir.

\section{İkinci Alt Probleme İlişkin Bulgular ve Yorumlar}

8. sınıf öğrencilerinin okuma ön yargılarını etkileyen faktörlerle ilgili görüşleri Tablo 3'te gösterilmiştir.

Tablo 3

8. Sını Öğrencilerinin Okuma Ön Yargılarını Etkileyen Faktörlerle İlgili Görüşleri

\begin{tabular}{|c|c|c|}
\hline Kategori & Yüzde & Örnek İfadeler \\
\hline $\begin{array}{l}\text { Cinsiyetle İlgili } \\
\text { Ön Yargılar }\end{array}$ & $\% 22,5$ & $\begin{array}{l}\text { K23: Kızların sabrının daha fazla olduğunu düşünüyorum. } \\
\text { K35: Erkekler daha hareketli, kızlar daha durgundur. Erkekler } \\
\text { eğlenecek şeyler bulabilir ama kızlar bulamazlar. Bu yüzden daha çok } \\
\text { kitap okurlar. }\end{array}$ \\
\hline $\begin{array}{l}\text { Sosyal Çevreyle İlgili Ön } \\
\text { Yargılar }\end{array}$ & $\% 45$ & $\begin{array}{l}\text { K2: Kitap okuyanlarla dalga geçilir. Kimse onunla arkadaş olmak } \\
\text { istemez. } \\
\text { K6: Çok kitap okuduğumuzda arkadaşlarımıza zaman ayıramayız. }\end{array}$ \\
\hline $\begin{array}{l}\text { Teknolojik Araçlarla } \\
\text { İlgili Ön Yargılar }\end{array}$ & $\% 52,5$ & $\begin{array}{l}\text { K11: Bir kitabın filmini izlemek daha zevkli ve kolay. } \\
\text { K24: Kitap okumak sıkıcıdır. Ama teknolojik aletlerle zaman geçirmek } \\
\text { çok eğlenceli. }\end{array}$ \\
\hline $\begin{array}{l}\text { Öğretmenle İlgili Ön } \\
\text { Yargılar }\end{array}$ & $\% 67,5$ & $\begin{array}{l}\text { K18: Öğretmen kitap okumaya zorlarsa öğrenci iyice nefret eder. } \\
\text { K20: Öğretmenler kitap okumamız yerine test çözmemizi tercih } \\
\text { ederler. }\end{array}$ \\
\hline Aileyle İlgili Ön Yargılar & $\% 70$ & $\begin{array}{l}\text { K4: Eğer anne babada kitap okuma alışkanlığı varsa çocuk da bu } \\
\text { alışkanlığı kazanır. Anne baba okumuyorsa çocuk da okumaz. } \\
\text { K33: Bir ailenin maddi durumu kötüyse kitap almaya imkân bulamaz } \\
\text { ve kitap okuyamaz. }\end{array}$ \\
\hline $\begin{array}{l}\text { Lise Giris Sınavlarıyla } \\
\text { İlgili Ön Yargılar }\end{array}$ & $\% 77,5$ & $\begin{array}{l}\text { K3: Lise giriş sınavı beni her şeyden soğuttu. } \\
\text { K24: Lise giriş sınavında başarılı olmam için test çözmem gerekiyor. } \\
\text { Kitap okumam değil. }\end{array}$ \\
\hline $\begin{array}{l}\text { Kitaplarla ilgili Ön } \\
\text { Yargılar }\end{array}$ & $\% 95$ & $\begin{array}{l}\text { K19: Kitabın kapağı ve adı kitap okumamızda etkilidir. } \\
\text { K17: Kitaplar bu kadar pahalı olmamalı. }\end{array}$ \\
\hline
\end{tabular}

Tablo 3 incelendiğinde en yüksek ön yargı sıklığının \% 95 ile "Kitaplarla İlgili Ön Yargılar" başlığında görüldügü göze çarpmaktadır. Onu sırasıyla Lise Giriş Sınavıyla İlgili Ön Yargılar $(\% 77,5)$, Aileyle İlgili Ön Yargılar (\%70), Öğretmenle İlgili Ön Yargılar (\%67, 5), Teknolojik Araçlarla İlgili Ön Yargılar $(\% 52,5)$, Sosyal Çevreyle İlgili Ön Yargılar $(\% 45)$ ve Cinsiyetle İlgili Ön Yargılar $(\% 22,5)$ takip etmektedir. 
En düşük ön yargı sıklık oranına sahip olan "Cinsiyetle İlgili Ön Yargılar" başlığında okuma alışkanlığının kız öğrencilerde daha yaygın olduğu ile ilgili genel bir kanıdan söz edilebilir. Sosyal çevreyle ilgili ön yargı örneklerinde de görüldüğü üzere öğrenciler, kitap okumanın sosyal ilişkilerine destek olmanın aksine zarar vereceğine inanmaktadırlar. Kitap okumakla zaman harcadıklarını düşünerek hızlı ve kolay olan teknolojik araçlara eğilmektedirler. Ayrıca kitap okumayı sıkıcı bir aktivite olarak nitelemektedirler. Öğrenciler, öğretmenlerin kitap okuma konusunda baskıc1 ya da ilgisiz olduklarını belirtmişlerdir. Bu durum öğrencileri okumadan uzaklaştırmaktadır. Öğretmenlerin, akademik başarı getireceğine inandıkları test tekniğine yoğunlaşmaları eleştirilen bir diğer durumdur. Anne babalarla ilgili "rol model" olamama sorunu öğrencilerce dile getirilmiştir. Ayrıca kitabın ancak maddi durumu iyi kişilerce okunabileceği ön yargısından da söz edilebilir. Lise giriş sınavıyla ilgili ön yargılar, genel itibarıyla olumsuzdur. Öğrenciler, bu sınavın onları okuma alışkanlığından uzaklaştırdığını düşünmektedirler. Kitap okumak, öğrencilerce "zaman kaybı" olarak algılanmaktadır. Okumayla ilgili en yüksek sıklık oranı "Kitaplarla İlgili Ön Yargılar" başlığına aittir. Kitapların pahalı ya da sıkıcı olması, ilgi çekici isim ve kapak tasarımlarına sahip olmaması gibi ön yargıları belirlenen öğrenciler bu sebeplerle okumadan uzaklaştıklarını dile getirmektedirler.

\section{Sonuç, Tartışma ve Öneriler}

Dört temel dil becerisinden biri olan okumanın eğitimdeki yeri ve önemi yadsınamaz. Okumayı öğrenmek ve yaşam boyu devam ettireceğimiz bir alışkanlık haline getirmek, eğitimin en temel hedeflerindendir (Arıcı, 2008; Arı ve Okur, 2013). Okumanın alışkanlık haline getirilmesi bireylere çok yönlü katkılar sağlar. Okuyan bireylerin sözcük dağarcığı ile birlikte kavrama kabiliyeti de gelişmektedir. Thorndike (1973) ve May'in (1986) araştırmaları (Akt. Ungan, 2008), bireylerin sözcük bilgisi ile anlama yetileri arasında yüksek korelasyon olduğunu göstermiştir. On beş ülke ve yüz bin çocuk üzerinde araştırma yapan Thorndike, sözcük dağarcığı fazla olan çocukların sınavlarda, hatta diğer derslerde daha başarılı oldukları sonucuna varmıştır. Aynı şekilde May, kelime bilgisinin anlama yeteneğini $\% 50$ oranında artırdığını vurgulamıştır.

Ancak Türkiye'de okuma kültürünün gelişmiş ülke ortalamalarının oldukça altında olduğu bilinmektedir (Aksaçlığlu ve Yılmaz, 2007). Bu sorun ilköğretimden üniversiteye kadar pek çok eğitim kademesine devam eden öğrencilerde gözlemlenmektedir. Odabaş vd. (2008), yaptıkları araştırmada üniversite öğrencilerinin de yeterli okuma alışkanlığına sahip olmadıkları sonucuna ulaşmışlardır.

Öğrencilerin okuma motivasyonunu sağlayan nedenler ilgi ve meraklarını kapsayan içsel nedenler olabileceği gibi aile, okul, arkadaş vb. nedenler de olabilmektedir. Yıldız ve Akyol (2011)'un araştırma sonuçları okuma motivasyonunun sağlanmasının okuduğunu anlamayı olumlu yönde etkilediğini göstermiştir. Okuduğunu anlama becerisinin gelişmesi, bireylerde okuma eylemini verimli kılacağı için okuma alışkanlığının edinilmesini de destekleyecektir.

Çalışmamızda 8. sınıf öğrencilerinin okuma ön yargıları çeşitli etmenler açısından incelenmiştir. Çalışma sonucunda en yüksek ön yargı sıklığının \% 95 ile "Kitaplarla İlgili Ön Yargılar" başlığında görüldüğü göze çarpmaktadır. Onu sırasıyla Lise Giriş Sınavıyla İlgili Ön Yargılar (\%77,5), Aileyle İlgili Ön Yargılar (\%70), Öğretmenle İlgili Ön Yargılar (\%67, 5), Teknolojik Araçlarla İlgili Ön Yargılar $(\% 52,5)$, Sosyal Çevreyle İlgili Ön Yargılar $(\% 45)$ ve Cinsiyetle İlgili Ön Yargılar $(\% 22,5)$ takip etmektedir.

Cinsiyetle ilgili ön yargılarda erkek öğrencilerin kız öğrencilerden daha fazla ön yargıya sahip oldukları sonucuna ulaşılmıştır. Erkek öğrenciler, kitap okuma konusunda kız öğrencileri kendilerinden çok daha istekli ve başarılı bulmaktadırlar. Ayrıca erkek öğrencilerde, kız öğrencilerin karakteristik özelliklerinin kitap okumaya daha uygun olduğu görüşü hakimdir. Can vd. (2010), yaptıkları çalışma sonucunda kız öğrencilerin okuma sıklıklarının erkek öğrencilere göre daha fazla olduğunu belirtmiş̧lerdir. Bu sonuç, çalışmamızın sonuçlarıyla örtüşmektedir. 
Teknolojik araçlarla ilgili erkek öğrencilerin ön yargı oranı kız öğrencilerin ön yargı oranının iki katıdır. Tüm ön yargılar içerisinde bu başlığın oranı ise \%52,5 olarak karşımıza çıkmaktadır. Aksaçlığlu ve Yılmaz (2007) yaptıkları araştırmada, öğrencilerin kitap okumak yerine bilgisayar kullanmayı ve televizyon izlemeyi tercih etmelerinin yanı sıra teknolojik araçlara eğilim arttıkça kitap okuma sıklığının azaldığı sonucuna ulaşmışlardır. Bu başlıkta görülen ön yargılar genelde teknolojik araçların hızlı ve eğlenceli olmasına karşın kitapların renksiz ve sıkıcı bulunması yönündedir. $\mathrm{Bu}$ nedenle yapılan pek çok araştırmada öğrenciler, zamanlarını en çok televizyon seyrederek geçirdiklerini belirtmişlerdir (Aral ve Aktaş, 1997).

Bireyin okumayı bir ihtiyaç olarak görüp alışkanlık haline getirmesi erken yaşlarda olması gereken bir durumdur ve ağırlıklı olarak aileye bağlıdır (Ar1 ve Okur, 2013). Aileyle ilgili ön yargılarda kız öğrenciler erkek öğrencilere göre \%20 daha fazla ön yargıya sahiptir. Kız öğrencilerin sosyal çevreyle ilgili ön yargılarda da erkek öğrencilerden daha fazla ön yargıya sahip olması dikkat çekicidir. Öğrenciler anne ve babaların okuma konusunda model olmalarının gerekliliği üzerinde durmuşlardır. Tanju (2010)'ya göre ebeveynler çocuklara okuma alışkanlığı kazandırmada model olmalıdır. Tanju ayrıca aile içi okuma zamanları yaratılması, kitaplar ve yazarları hakkında konuşulması ve kitap seçiminde yönlendirmeler yapılmasının gerekliliğini vurgulamıştır. Durualp vd. (2013)'nin, 8. sınıf öğrencilerinin kitap okumaya yönelik tutumlarını inceledikleri çalışmalarında, internet kullanımı ailesi tarafından denetlenen, interneti ödev ve bilgilendirme amaçlı kullanan, kitaplığı olan, ailesi sık sık kitap satın alan çocukların kitap okuma tutumları önemli düzeyde yüksek bulunmuştur. Aileler çocuklara her firsatta kitap hediye etmeli, çocukta kitabın sevindirici ve değerli bir şey olduğu izlenimi uyandırmalıdır (Duran ve Sezgin, 2012).

Öğrenciler ailelerin ekonomik düzeylerinin de okumada etkili olduğunu düşünmektedirler. Şahin (2009) ve Coşkun (2013)'un çalışmalarında, öğrencilerin okumaya olan ilgileri ile ailelerin sosyo-ekonomik düzeyleri arasında yüksek düzeyde ilişki olduğu sonucuna ulaşılmıştır. Bu sonuçlar, araştırmamızın sonuçlarıyla benzerlik göstermektedir.

Öğrencilere rahat bir okuma ortamının sağlanması ve evde zengin bir kitaplık oluşturulmasında ailelerin ekonomik düzeylerinin etkili olduğu görülmektedir. Kendisine ait odası ve çalışma masası olmayan öğrenciler dikkatlerini okudukları kitaba uzun süre yoğunlaştıramazlar. Yatak ya da koltukta okuyan çocuk uyuma eğilimine girerek, televizyonun karşısında okuyan çocuk da ilgisini televizyona yönlendirerek okuma eyleminden uzaklaşır. Bu gibi durumlar çocukta okumanın sıkıcı ve kitapların karmaşık olduğu ön yargısını doğurur.

Öğrencilerin anne baba eğitim durumları ile okuma ön yargıları arasında anlamlı bir ilişki saptanmamıştır. Can vd. (2010)'nin yaptıkları araştırma, bu araştırmanın sonuçlarıyla örtüşmektedir. Can vd, yaptıkları araştırmada anne ve baba eğitim düzeyinin okuma sıklığını artırdığı sonucuna ulaşmışlardır. Bu sonuç, çalışmamızın sonuçlarıyla çelişmektedir. Ancak Wolf, King ve Huck (1968; akt. Sadioğlu ve Bilgin, 2008), eleştirel okuma becerisine sahip olmanın okuma becerisi ve alışkanlığına sahip olma ile yüksek bir ilişkisi olduğunu belirtmektedirler. Sadioğlu ve Bilgin (2008), öğrencilerin eleştirel okuma becerileri ile anne baba eğitim durumları arasındaki ilişkiyi inceledikleri çalışmalarında, anne babaların eğitimli olmalarının çocukların eleştirel okuma becerilerini farklılaştırmadığı sonucuna ulaşmışlardır. Bu sonuç, çalışmamızın sonuçlarıyla örtüşmektedir.

Üst düzey eğitim alan anne ve babaların daha fazla kitap okumaları, evlerinde daha fazla kitap bulundurmaları ve böylece çocuklarına rol model olabilmeleri; ayrıca çocuklarıyla kitaplar ve yazarlar hakkında daha fazla sohbet edip kitap seçimlerinde daha etkili önerilerde bulunabilmelerinin bu sonuçta etkili olduğu düşünülmektedir.

Okuma eyleminin zaman kaybı olduğunu düşünen öğrenciler bu eylemin arkadaşlarına zaman ayırmalarına da engel olduğu kanısındadırlar. Zaman yönetimiyle ilgili olumsuz düşünceler lise giriş sınavlarıyla ilgili ön yargılarda da ön plana çıkmaktadır. Öğrenciler lise giriş sınavlarında başarılı olabilmek için kitap okumak yerine test çözmeleri gerektiğini düşünmektedirler. Ebeveyn ve öğretmenlerin bu yöndeki beklentileri de öğrencilerin ön yargı oluşumunda etkilidir. Hem kız hem de erkek öğrencilerde yüksek oranda tespit edilen lise giriş sınavlarıyla ilgili ön yargılar, katılımcıların 
\%77,5'inde görülmekte ve en yüksek ikinci ön yargı oranı olarak karşımıza çıkmaktadır. Şahin (2009), yaptığ1 araştırmada öğrencilerin ders yoğunluğu ve sınav kaygılarının kitap okumalarına engel olduğu sonucunalaşmıştır.

Öğrencilerin en fazla ön yargıya sahip olduğu başlık \%95 oran ile "Kitaplarla İlgili Ön Yargılar" başlığıdır. Öğrenciler kitapların şekilsel özelliklerinin okumada etkili olduğunu sıklıkla dile getirmişlerdir. Kitap seçimlerinde kitabın başlığının yanı sıra kapak görseli, yazarın tanıtımı, romanın tanıtımı, fiyatı vb. özellikleri öğrencilerin okuma eğilimlerini etkilemektedir. Kitapların içeriği kadar fiziksel özellikleri de özellikle ilköğretim çağındaki çocuklar için, tercih sebebi olmaktadır. (Şahin, 2009) $\mathrm{Bu}$ nedenle kitaplar görsel unsurlarla zenginleştirilmeli, öğrencilerin ilgini çekecek nitelikte hazırlanmalıdır. Smith vd. (1998)'ne göre öğrencilerin okuma alışkanlığı kazanması için kitap seçimlerine saygı duyulmalıdır. Ancak günümüzde, reklam ve pazarlama amacıyla kitapların kapak tasarımlarında propaganda tekniklerinin kullanıldığı görülmektedir (Kaplan, 2017) Öğrencilerin yanı sıra anne babaların ve hatta öğretmenlerin kitaplarla ilgili doğru seçim yapabilmesi için propaganda teknikleri konusunda bilgilendirilmeleri gerekmektedir. Duran ve Sezgin (2012), toplumda kitabın bir ihtiyaç haline gelmediği, yaşamsal bir gereklilik olduğu algısı hakim olmadığı ve değer yargılarında birinci sırada yer almadığı sürece kitap okuma alışkanlığıyla ilgili sorunun ortadan kalkmayacağını belirtmişlerdir.

Okuma ön yargıları sıralamasında "Öğretmenle İlgili Ön Yargılar" başlığı \%67,5 oranla 4. sırada yer almaktadır. Öğrenciler öğretmenleri kitap okuma konusunda baskıcı ya da ilgisiz bulmaktadırlar. Öğretmenlerin kitap seçimi konusunda öğrencileri sınırlandırmaları veya lise giriş sınavındaki akademik başarıyı yükseltme kaygısıyla test çözmeye yönlendirmeleri öğrencilerde ön yargıların oluşmasına neden olmaktadır. Ayrıca öğrenciler, öğretmenlerin kitap okumadıklarını buna rağmen kendilerinden kitap okumalarını istediklerini belirtmişlerdir.

Öğrencilerin okuma becerilerinin gelişmesinde ve onlara okuma alışkanlığı kazandırılmasında öğretmenlerin etkisi büyüktür (Gündoğmuş ve Çayır, 2016). Öğretmenler eğitimde başarının en önemli belirleyicisi olarak kabul edilmektedir (Aşılığlu, 2008). Öğrencilere model olmanın önemine değinen Ülper'e (2011) göre öğretmenlerin okuma güdülerinin yüksek olması ve sıklıkla bu edinimi gerçekleştirmeleri öğrencileri olumlu yönde etkileyecektir. Günümüzde öğretmen sadece bilgi veren ve onu değerlendiren bir birey olmaktan çıkmıştır. Modern eğitim anlayışının öğretmeni, çocuğun duyan, düşünen ve uygulayan bir insan olması yolunda deneyim kazanmasıyla yakından ilgilenir (Mete, 2012). Yapılan araştırmalar \%70,7'lik bir oranla öğretmenlerin, çocuklara kitap okuma alışkanlığı kazandırmada en büyük etkiyi yapan kişiler olduğunu göstermektedir (Özbay vd., 2008). Fakat öğretmenin kendisinde olmayan bir alışkanlığı öğrencilere aktarabileceğini düşünmek hata olacaktır. Yapılan araştırmalar öğretmenlerin, öğrencilerin okuma ön yargılarını olumlu hale getirme konusunda fazla çaba harcamadıklarını, okuma ilgi ve alışkanlıklarının yeterli düzeyde olmadığını göstermektedir (Aslantürk ve Saracaloğlu, 2010; Saracaloğlu vd., 2010, Saracaloğlu vd., 2009; Yılmaz vd., 2009).

Batur vd.nin (2017) "Türkçe Eğitimi ve Yabancı Dil Öğretiminde Dört Temel Dil Becerisinin Edinimine İlişkin Öğretmen Görüşleri” başlıklı çalışmalarında Türkçe öğretmenleri okuma ortamlarının sınırlarının genişletilmesi gerektiğini belirtmiş ve tüm branş öğretmenlerinin okuma konusunda rol model olmaları gerektiğini vurgulamışlardır. Okuma eğitiminde paydaşların sürece dahil olmasını Arıcı (2015) da desteklemektedir. Okuma alışkanlığının, sınıf ve Türkçe öğretmenleri başta olmak üzere tüm branş öğretmenlerine lisans eğitiminde kazandırılması yerinde olacaktır. Öğretmeni okumayan öğrencilerin okuma konusunda güdülenmesi ve ön yargilarından kurtulmas1 güçtür. Bu nedenle eğitim fakültelerinin Türkçe öğretmenliği ana bilim dalı dışındaki diğer ana bilim dallarında öğrenim gören öğretmen adaylarının da okuma alışkanlığına yönelik tutumları belirli aralıklarla gözden geçirilmeli ve olumlu tutum kazanmalarına yönelik etkinlikler yapılmalıdır. Öğretmen adaylarının okuma problemlerinin ortaya konulması amacıyla yapılan akademik çalışmalar ile okuma teknikleri, okuma stratejileri ve okuma ön yargılarına yönelik çalışmalar arttırılmalıdır. Öğretmenler ayrıca, tüm öğrencilere firsat eşitliği sağlamak ve onları kitaplarla buluşturmak amacıyla okul kütüphanelerini geliştirme çabası içinde olmalıdır. Okul kütüphanesinin etkin şekilde 
kullanılması amacıyla çeşitli girişimlerde bulunmalı, yazar ve kitap tanıtımları ile ilgili projeler geliştirmelidir.

Öğrenciler, teknolojik araçlara bağımlılık ya da sınav kaygıları gibi nedenlerle okumaya verimli ve yeterli düzeyde zaman ayıramamaktadırlar. Teknolojik araçlarla geçirdikleri zamanın akışını kontrol edememekte ya da sınav kaygıları nedeniyle okumayı zaman kaybı olarak görmektedirler. Bu sorunu çözebilme adına zaman yönetimi ile ilgili bir dersin eğitim programımıza dahil edilmesi ya da öğrencilerin bu konuda rehberlik çalışmaları ile bilinçlendirilmesinin yararlı olacağı düşünülmektedir. Ayrıca eğitimin temelinde yer alan aile faktörüne ilişkin ön yargıların önlenmesi amaciyla öğrenci ve ebeveynleri kapsayan; ebeveynleri bilinçlendirmeye, öğrencileri ise hem bilinçlendirmeye hem de onlara okuma alışkanlığ 1 kazandırmaya yönelik projelerin gerçekleştirilmesi yerinde olacaktır. 


\section{Kaynaklar}

Aksaçlığlu, A. G. ve Yılmaz, B. (2007). Öğrencilerin televizyon izlemeleri ve bilgisayar kullanmalarının okuma alışkanlıkları üzerine etkisi. Türk Kütüphaneciliği, 21(1), 3-28.

Anderson, E. (1996). The influence of embedded word-study instruction, social context, and motivation of children's independent reading and writing: A case study of 3 first-graders. Reading Research Report No. 65.

Aral, N. ve Aktaş, Y. (1997). Çocukların televizyon ve diğer etkinliklere harcadıkları sürenin incelenmesi. Hacettepe Üniversitesi Eğitim Fakültesi Dergisi, 13, 99-105.

Arı, G. ve Okur, A. (2013). Öğrencilerin ilköğretim 100 temel eseri okuma durumu. Türkiye Sosyal Araştırmalar Dergisi, 173, 307-328.

Arıcı, A.F. (2008). Okumayı niye sevmiyoruz: Üniversite öğrencileriyle mülakatlar. Mustafa Kemal Üniversitesi Sosyal Bilimler Enstitüsü Dergisi: 5(10), 91-100.

Arıcı, A. F. (2015). Türkçe öğretmenleri / öğretmen adayları ne okumalı? -bir "okuma listesi" önerisi. Hacettepe Üniversitesi Eğitim Fakültesi Dergisi, 30(3), 1-15.

Arslan, Y., Çelik ve Z. Ç. E. (2009). Üniversite öğrencilerinin okuma alışkanlığına yönelik tutumlarının belirlenmesi. Pamukkale Üniversitesi Eğitim Fakültesi Dergisi, 26(26), 113-124.

Aslantürk, E. ve Saracaloğlu, A. S.(2010). Sınıf öğretmenlerinin ve sınıf öğretmeni adaylarının okuma ilgi ve alışkanlıklarının karşılaştırılması. Anadolu Üniversitesi Sosyal Bilimler Dergisi, 11(1), $155-176$.

Aşılıŏlu, B. (2008). Bilişsel öğrenmeler için eleştirel okumanın önemi ve onu geliştirme yolları. Dicle Üniversitesi Ziya Gökalp Ĕ̈itim Fakültesi Dergisi, 10, 1-11.

Balc1, A. (2009). İlköğretim 8. sınıf öğrencilerinin kitap okuma alışkanlığına yönelik tutumları. Mustafa Kemal Üniversitesi Sosyal Bilimler Enstitüsü Dergisi, 6(11), 265-300.

Balcı, A., Uyar, Y. ve Büyükikiz, K. K. (2012). İlköğretim 6. Sınıf Öğrencilerinin Okuma Alışkanlıkları, Kütüphane Kullanma Sıklıkları ve Okumaya Yönelik Tutumlarının İncelenmesi. Turkish Studies, 7(4), 965-985,

Batur, Z. ve Bek, H. G. H. (2010). Öğretmen adaylarının okuma alışkanlıkları üzerine bir araştırma: Uşak Eğitim Fakültesi örneği. Uşak Üniversitesi Sosyal Bilimler Dergisi, 3(1), 32-49.

Batur. Z., Erkek, G., Kaplan, K. ve Ercan, E. (2017). Türkçe eğitimi ve yabancı dil olarak ingilizce öğretiminde dört temel dil becerisinin edinimine ilişkin öğretmen görüşleri. Avrasya Dil Eğitimi ve Araştırmaları Dergisi, 1(1), 42-75.

Bircan, İ. ve Tekin, M. (1989). Türkiye'de okuma alışkanlığının azalması sorunu ve çözüm yolları. Ankara Üniversitesi Ë̆itim Bilimleri Fakültesi Dergisi, 22(1), 393-410.

Bostanoğlu, O. (2015). 9. sınıf öğrencilerin yazılı anlatımlarındaki önyargıların incelenmesi. Yayımlanmamıs yüksek lisans tezi, Çanakkale On Sekiz Mart Üniversitesi, Çanakkale.

Can, R., Türkyılmaz, M. ve Karadeniz, A. (2010). Ergenlik dönemi öğrencilerinin okuma alışkanlıkları. Ahi Evran Üniversitesi Eğitim Fakültesi Dergisi, 11(3), 1-21.

Chua, S. P. (2008). The effects of the sustained silent reading program on cultivating students habitsand attitudes in reading boks for leisure. Heldref Publication, 81(4), 180-184.

Coşkun, E. (2003). Çesitli değiskenlere göre lise öğrencilerinin etkili okuma becerileri ve bazı öneriler. Türklük Bilimi Araştırmaları, 13, 101-130.

Duran, E. ve Sezgin, B. (2012). İlköğretim 4 ve 5. sınıf öğrencilerinin okuma alışkanlıkları ve ilgilerinin belirlenmesi. Turkish Studies, 7(4), 1649-1662.

Durualp, E., Çiçekoğlu, P. ve Durualp, E. (2013). Sekizinci sınıf öğrencilerinin kitap okumaya yönelik tutumlarının internet ve kitap okuma alışkanlıkları açısından incelenmesi. Uluslararası Türkçe Edebiyat Kültür Eğitim (TEKE) Dergisi, 2(1). 115-132.

Gündoğmuş, H. D. ve Çayır, A. (2016). Öğretmen adaylarını kitap okumak için en çok ne güdülemektedir? Turkish Studies, 11(3), 2613-2622.

Gürses, İ. (2005). Önyargının nedenleri. Uludağ Üniversitesi Illahiyat Fakültesi Dergisi, 14(1), 143160.

İşcan, A., Arıkan, İ. B. ve Küçükaydın, M. A. (2013). İlköğretim ikinci kademe öğrencilerin kitap okuma alışkanlıkları ve okumaya ilişkin tutumları. Uluslararası Avrasya Sosyal Bilimler Dergisi,4(11), 1-16. 
Jones, M. (2002). Social Psychology of Prejudice. New Jersey: Prentice Hall.

Kaplan, K . (2017). Kitapların kapak tasarımlarındaki mesajlarda kullanılan propaganda teknikleri. Uluslararası Türkçe Edebiyat Kültür Eğitim (TEKE) Dergisi, 6(3), 1574-1589.

Karataş, Z. (2015). Sosyal bilimlerde nitel araştırma yöntemleri. Manevi Temelli Sosyal Hizmet Araştırmaları Dergisi, 1(1), 32-80.

Kurulgan, M. ve Çekerol, G. S. (2008). Öğrencilerin okuma ve kütüphane kullanma alışkanlıkları üzerine bir araştırma. Anadolu Üniversitesi Sosyal Bilimler Dergisi, 8(2), 237-258.

Mete, G. (2012). İlköğretim 8. sınıf öğrencilerinin okuma alışkanlığı üzerine bir araştırma (Malatya ili örneği). Dil ve Edebiyat Eğitimi Dergisi, 1(1), 43-66.

Odabaş, H. Odabaş ve Z. Y. Polat, C. (2008). Üniversite öğrencilerinin okuma alışkanlığı: Ankara Üniversitesi örneği. Bilgi Dünyast. 9(2), 431-465.

Özbay, M., Bağcı, H. ve Uyar, Y. (2008). Türkçe öğretmeni adaylarının okuma alışkanlığına yönelik tutumlarının çeşitli değişkenlere göre değerlendirilmesi. İönü Üniversitesi Eğitim Fakültesi Dergisi, 9(15), 117-136.

Özdemir, M. (2010). Nitel Veri Analizi: Sosyal Bilimlerde Yöntembilim Sorunsalı Üzerine Bir Çalışma. Eskişehir Osmangazi Üniversitesi Sosyal Bilimler Dergisi, 11(1), 323-343.

Plous, S. (2003). The Psychology of Prejudice, Stereotyping and Discrimination: An Overview, Understanding of Prejudice and Discrimination. (Ed.: Scott Plous). New York: McGraw Hill.

Sadioğlu, Ö. ve Bilgin, A. (2008). İlköğretim öğrencilerinin eleştirel okuma becerileri ile cinsiyet ve anne-baba eğitim durumu arasındaki ilişki. İlköğretim Online, 7(3), 814-822.

Sağıroğlu, A.Z.(2014). Türkiye'de etnisite, din ve önyarg1: Üniversite öğrencileri örneği. Yayımlanmamış doktora tezi, Selçuk Üniversitesi, Konya.

Sanacore, J. (2000). Promoting The Lifetime Reading Habit in Middle School Students. The Clearing House, 73 (3), 157-161

Saracaloğlu, A. S., Yenice, N., Karasakaloğlu, N. (2009). Öğretmen adaylarının iletişim ve problem çözme becerileri ile okuma ilgi ve alışkanlıkları arasındaki ilişki. Yüzüncü Yıl Üniversitesi Ĕ̈itim Fakültesi Dergisi, 6(2), 187-206.

Saracaloğlu, A. S., Karasakaloğlu, N. ve Aslantürk, U. E. (2010). Sınıf öğretmeni adaylarının okuma ilgi ve alışkanlıklarının karşılaştırılması. Adnan Menderes ve Uludağ Üniversiteleri örneği. Çukurova Üniversitesi Sosyal Bilimler Enstitüsü Dergisi, 19(3), 457-480.

Schunk, D. H. ve Zimmerman, B. J. (2007). Influencing children's self-efficacy and self-regulation of reading and writing through modeling. Reading \&Writing Quarterly, 23, 7-25.

Smith, C., Tracy, E., ve Weber, L. (1998). Motivating independent reading. https://archive.org/details/ERIC_ED422559

Şahin, A. (2009). İlköğretim 6. 7. ve 8. sınıf öğrencilerinin kitap okuma alışkanlıklarının sosyoekonomik düzeylerine göre incelenmesi. Mersin Üniversitesi Ĕgitim Fakültesi Dergisi, 5(2), 215-232.

Tanju, E. H. (2010). Çocuklarda Kitap Okuma Alışkanlığına Genel Bir Bakış. Aile ve Toplum, 6(21), 30-39.

Ungan, S. (2008). Okuma alışkanlığımızın kültürel altyapısı. Gaziantep Üniversitesi Sosyal Bilimler Dergisi, 7(1). 218-228.

Ülper, H. (2011). Öğrenci Açısından Okumaya Güdüleyici Etmenler. Kuram ve Uygulamada Eğitim Bilimleri Dergisi, 11(2), 941-960.

Ülper, H. ve Çeliktürk, Z. (2013). Öğretmen adaylarının okuma motivasyonlarının değerlendirilmesi: Mehmet Akif Ersoy Üniversitesi örneği. Adlyaman Üniversitesi Sosyal Bilimler Enstitüsü Dergisi, Türkçenin Ĕgitimi Öğretimi Özel Saylsı, 6(11), 1033-1057.

Yıldırım, A. ve Şimşek, H. (2008). Sosyal bilimlerde nitel araştırma yöntemleri. Ankara: Seçkin.

Yıldız, M. ve Akyol, H. (2011). İlköğretim 5. sınıf öğrencilerinin okuduğunu anlama, okuma motivasyonu ve okuma alışkanlıkları arasındaki ilişki. Gazi Üniversitesi Gazi Eğitim Fakültesi Dergisi, 31(3), 793-815.

Yıldız, N. ve Keskin, H. (2016). Ergenlik dönemindeki öğrencilerin dijital ve matbu okumaya karş1 tutumlarının çeşitli değişkenlere göre değerlendirilmesi. Mersin Üniversitesi Eğitim Fakültesi Dergisi, 12(1), 344-361. 


\section{Extended Abstract}

\section{Introduction}

Students' reading prejudices are generally about gender, family, school, teacher, social environment and books. The family, first and foremost step for becoming a role model, emerges as an element that causes negative motivation to the students for reading. Indifference of the families of the students; tendencies of the teachers to solve the tests; the fact that the students are not brought together with interesting books, negative peer models, etc., negatively affect the reading motivation of students.

In order to gain the habit of reading to the students, it is necessary to know the elements that prevent reading and to present the studies made regarding this subject (Aric1, 2008). The most effective individuals at preventing the prejudice are parents and teachers. The prejudices that began to occur at very young ages, become to be permanent once they are not reduced and eliminated over time. The prejudices of the children in the middle school age develop so rapidly along with their physical, emotional and mental skills. Therefore, the fact that reading not only remains as an advice, but also means supporting the words with behaviours, detecting and eliminating the negative prejudices of students against reading is very significant for gaining this habit.

\section{Purpose and Method of Study}

In this study, the reading prejudices of $8^{\text {th }}$ grade students have been researched. In line with this purpose, the sub-problems of the research have been determined as follows:

1. Would the frequency levels of factors which affect the reading prejudices of students at middle school $8^{\text {th }}$ grade be different;

a. according to gender,

b. according to the educational background of the parents?

2. What are the views of the students at middle school $8^{\text {th }}$ grade about the factors that affect the reading prejudices?

In this research, a qualitative research model and a phenomenological pattern that deal with events and facts according to people with social characteristics have been used.

A total of 40 students, 20 female and 20 male students, who study at the 8 th grade in 2017-2018 education year in Uşak, constitute the study group. The study group has been formed with the principle of volunteerism and easy accessibility.

A semi-structured interview form consisting of seven open-ended questions has been used in the study to determine the reading prejudices of $8^{\text {th }}$ grade students. The form has been configured and finalized by the three expert opinions. The questions in the interview form are as follows; Do you think that the reading habits vary with the gender, attitudes of the parents, attitudes of the teachers, the social environment, the qualifications of the books, the thoughts and expectations of the high school entrance exam? Why?

In this study, validity and reliability have been tried to be ensured by considering the concepts of consistency, transferability and verifiability used in the qualitative researches. The research data have been generated by receiving expert opinions. Common points have been examined by three researchers, leading experts in their fields, and endeavoured to be presented objectively. The study group has been generated through purposeful sampling. Furthermore, it has been contributed to the content validity by including the sample sentences from the discourses of the participants at the second sub-problem. 
The data obtained through making descriptive analysis for the first sub-problem; thematic coding for the second sub-problem of the research have been categorized. Percentage rates and sample expressions have been given for each category. The views of the students have been evaluated by being compared to the other findings and remarks within the literature.

\section{Result and Discussion}

As a result of the study, it is in evidence that the highest prejudice frequency is at the title of "Prejudices About Books" with the rate 95\%. Respectively, Prejudices About High School Entrance Exam (77,5\%), Prejudices About Family (70\%), Prejudices About Teacher (67,5\%), Prejudices About Technological Tools (52,5\%), Prejudices About Social Environment (45\%) and Prejudices About Gender (22,5\%) follows it.

It has been found that the gender is a significant factor for reading prejudice. It has been concluded that the male students have more prejudice than female students do. Male students find the female students to be more willing and successful in reading books than themselves. Also, it is a common belief of the male students that the characteristics of the female students are more appropriate for reading books. As a result of their study, Can, and others (2010) have stated that the frequency of reading books is higher at the female students compared to the male students.

Students believe that the educational backgrounds of their parents affect the reading prejudice. The fact that the parents with the level of higher education read more books, have more books at their houses and so that they can be role models for their children; also, discuss more about books and authors with their children and make more influential suggestions in book selection has been thought to be effective at this result. 